\title{
PENELITIAN STUDI KASUS FENOMENOLOGI PERSEPSI KEADILAN PELAKU PEMBUNUHAN ANGGOTA PKI 1965
}

\author{
Kukuh Setyo Pambudi \\ Ceria Institute \\ kukuhpambudi@ymail.com \\ Indah Yasminum Suhanti \\ Prodi Psikologi, Fakultas Pendidikan Psikologi, Universitas Negeri Malang
}

\begin{abstract}
Abstrak
Penelitian ini bertujuan untuk mendeskripsikan persepsi keadilan pelaku pembunuhan anggota PKI tahun 1965. Rancangan penelitian yang digunakan adalah kualitatif dengan model studi kasus fenomenologi. Subjek penelitian berjumlah 3 orang, mereka menjadi pelaku pembunuhan anggota PKI 1965. Data primer didapatkan dengan wawancara mendalam. Kemudian data sekunder didapatkan dari informan, studi dokumen, observasi, dan catatan lapangan. Hasil penelitian memperlihatkan subjek memiliki persepsi bahwa pembunuhan anggota PKI merupakan hal yang adil. Persepsi keadilan subjek dijabarkan dalam empat bentuk keadilan, yakni protektif, prosedural, retributif, dan restoratif. Secara protektif, subjek memiliki persespsi keadilan yang menyebutkan bahwa pembunuhan anggota PKI adil karena dilakukan sebagai bentuk perlindungan diri. Selain itu secara prosedural, subjek menilai bahwa pembunuhan anggota PKI adil dengan tidak melangar prosedur yang ditetapkan. Secara retributif dan restoratif subjek menyatakan pembunuhan anggota PKI merupakan bentuk hukuman yang adil dalam upaya memulihkan kondisi sosial dan politik.
\end{abstract}

Kata Kunci : persepsi keadilan, pelaku pembunuhan, peristiwa tahun 1965, studi kasus fenomenologi.

\begin{abstract}
This Research is aiming to describe the justice perception of PKI member murderers in 1965 ,research uses qualitative design with phenomenological case study model. There were three participants on this research who were respectively known as the murder. Accordingly, the primary data obtained in this research is collected by using unstructured in-depth interview. Moreover, the secondary data are obtained by using informants, documents study, observations, and field notes. The result of this research reveals that participants have a perception that PKI member murderer was a fair issue. The participant justice perceptions are described into four categories of justice perceptions: protective, retributive, procedural, and restorative. In protective, participants have justice perceptions mentioning that PKI member murderer is fair because it makes them protected. Furthermore, on procedural justice, participants stated that the murderer did not break the rules already determined as what it is said so. Lastly, for retributive and restorative, the participants also mentioned that the criminal act done by PKI members is a form of punishment and an attempt to restore the condition like beforehand.
\end{abstract}

Keywords: justice perception, murderer, the tragedy of 1965, phenomenological case study.

Dalam sejarah Indonesia, tahun 1965 merupakan salah satu tahun yang penuh dengan permasalahan politik, ekonomi, dan sosial. Tahun tersebut menjadi awal titik balik kekuasaan dari tangan Presiden pertama Indonesia yakni Soekarno, yang kemudian berbalik menjadi landasan untuk memulai masa“orde baru" dengan Soeharto sebagai
Presiden. Momentum yang paling banyak dibicarakan dan dicatat dalam sejarah adalah adanya peristiwa pada malam tanggal 30 September 1965 yang kemudian dikenal sebagai Gerakan 30 September.

Sampai saat ini memang masih terjadi perdebatan tentang Gerakan 30 September. Banyak pendapat yang menyebutkan bahwa 
Gerakan 30 September jelas - jelas melakukan tindakan yang tidak patut dengan membunuh para Jenderal, namun pendapat lain yang menentang beberapa menyatakan sebenarnya Gerakan 30 September hanyalah alat politik dalam upaya pergantian rezim. Salah satu pendapat yang mendukung Gerakan 30 September sebagai alat politik adalah Roosa (2008) yang menyebutkan dalam dokumen Suparjo tidak diketahui secara pasti tentang siapa yang menjadi pemimpin dari Gerakan 30 September.

Saat ini banyak sekali muncul usaha untuk mempermasalahkan peristiwa ini beserta pelakunya yang dicoba diangkat melalui banyak cara. Seperti yang terlihat pada acara yang diselenggarakan baik pemerintah maupun swasta bertajuk 1965. Hal tersebut berimbas pada kemungkinan penilaian searah serta ke wenang - wenang terhadap para pelaku pembunuhan anggota PKI kala itu tanpa didasari penilaian yang objektif. Peneliti menganggap perlu melihat sisi lain di luar banyaknya desakkan membawa kasus ini pada peradilan HAM yang mempersoalkan para pelaku dari sudut pandang apa yang sudah mereka lakukan.

Salah satu kajian yang dapat menambah objektifitas dalam pemecahan masalah peristiwa 1965 adalah dengan melihat sudut pandang keadilan dari pelaku. Penilaian tentang adil dan tidaknya suatu perbuatan dalam psikologi merupakan bentuk dari persepsi. Persepsi adalah proses kognitif yang bertujuan untuk memproses stimulus atau hal - hal yang berada di luar individu untuk menjadikannya sebuah deskripsi subjektif oleh individu tentang stimulus atau hal - hal yang ada di lingkungan individu tersebut. Sejalan dengan penjelasan tersebut, Sobur (2003) menjelaskan bahwa persepsi adalah cara manusia menangkap rangsangan. Selain itu disebutkan juga oleh Hanurawan (2010) bahwa persepsi merupakan sejenis aktivitas pengelolaan informasi yang menghubungkan seseorang dengan lingkungannya. Berdasarkan definisi persepsi, dapat diketahui bahwa persepsi memiliki peranan yang penting dalam menentukan perilaku seseorang.
Dalam menentukan perilaku, persepsi yang dimiliki seseorang tidak dibuat secara instan dan statis. Seseorang akan selalu melakukan penghayatan mendalam mengenai perspesi yang akan mengerakkan perilakunya. Dijelaskan oleh Stephan \& Stephan (dalam Hanurawan, 2010) bahwa sebagai upaya memahami keseluruhan gambaran komprehensif tentang diri orang lain, dalam pembentukan persepsi, seseorang mendayagunakan segenap informasi yang dimiliki untuk membentuk kesan - kesan (impressions) tentang orang lain. Pentingnya mempelajari persepsi seseorang adalah untuk mengetahui motif seseorang terhadap yang telah dilakukan. Hal tersebut dimungkinkan karena persepsi adalah penentu respon seseorang. Sobur (2009) menjelaskan, persepsi menentukan individu memilih suatu pesan dan mengabaikan pesan yang lainnya. Sehingga jelas, apabila seseorang akan melakukan sesuatu pasti didahului oleh proses pembentukan persepsi yang akan mengarahkan tindakannya.

Salah satu objek yang juga digerakkan oleh persepsi adalah Keadilan. Keadilan merupakan kondisi atau nilai yang dihayati menjadi kondisi atau nilai yang paling seimbang dan tidak merugikan. Kondisi tersebut dapat terjadi dalam lingkup antar individu dan antar kelompok yang berada dalam suatu sistem atau institusional, baik menyangkut benda ataupun orang. Penjelasan di atas didukung oleh pendapat Rawls (1999) yang mendefinisikan keadilan sebagai "the first virtue of social institutions, as a truth is of systems of thought" atau jika diterjemahkan dalam bahasa Indonesia, keadilan adalah kebajikan (virtue) pertama dari institusi sosial, sebagaimana halnya kebenaran pada sistem pemikiran. Chan (2011) menjelaskan persepsi keadilan merupakan konsep sentral dalam psikologi organisasi, telah terbukti dalam penelitian menjadi penting dalam konteks yang beragam seperti seleksi karyawan dan staf, penilaian kinerja, kompensasi dan tunjangan, alokasi sumber daya, resolusi konflik , PHK, dan fungsi sumber daya manusia lainnya. Persepsi keadilan juga memainkan peran penting dalam implementasi kebijakan publik dan upaya keterlibatan masyarakat, serta keterlibatan karyawan dan upaya 
pengembangan organisasi berkaitan dengan masalah sikap, iklim dan perilaku.

Menelaah bagaimana seseorang memahami atau mempersepsikan konsepsi dari keadilan akan menjadi sangat menarik jika dikaitkan dengan peristiwa pembunuhan anggota PKI yang masih menjadi perdebatan sampai sekarang. Dengan mengetahui persepsi keadilan pelaku pembunuhan anggota PKI, akan dapat dilihat motif dari pelaku melakukan hal tersebut. Selain itu dapat pula diketahui bagaimana konsep keadilan yang ada dalam persepsi mereka para pelaku. Sehingga dapat memberikan perspektif baru terkait permasalahan pembunuhan anggota PKI pada tahun 1965 yang saat ini tengah didengungkan lagi untuk digelarnya permintaan maaf dan rekonsiliasi Negara dengan korban dan keturunan para korban tragedi tahun 1965.

\section{METODE}

Penelitian ini mengunakan pendekatan penelitian kualitatif. Penelitian kualitatif merupakan pendekatan penelitian yang mencoba mengungkapkan pemakanaan secara khusus dari tiap - tiap sudut pandang subjek secara subjektif dan bertujuan untuk mengali makna terdalam dari subjek tersebut tentang suatu fenomena. Hanurawan (2012) menjelaskan bahwa penelitian kualitatif dalam psikologi merupakan metode penelitian yang mendeskripsikan objek penelitian melalui prosedur dan data yang bersifat non numerikal (non angka) terhadap objek psikologi, seperti data verbal, teknik analisis isi, teknik analisis konservasi, kelompok fokus, analisis diskursus, dan fenomenologi untuk mengungkap objek fenomena psikologi.

Penelitian ini mengunakan model penelitian studi kasus fenomenologi. Rancangan penelitian studi kasus fenomenologi merupakan rancangan penelitian yang berusaha mengungkapkan dan memahami suatu kasus atau fenomena tertentu yang memiliki hubungan dengan esensi pengalaman individu tentang suatu fenomena yang dialami. Herdiansyah (2015) menjelaskan penelitian studi kasus merupakan rancangan penelitian yang bersifat komprehensif, intens, memerinci, dan mendalam, serta lebih diarahkan sebagai upaya untuk menelaah masalah - masalah atau fenomena yang bersifat kontemporer (berbatas waktu). Pertimbangan dalam mengabungkan kedua rancangan penelitian tersebut mengacu pada pendapat Hanurawan (2016) yang menyatakan penelitian studi kasus dapat digabung dengan model - model atau rancangan penelitian yang lain, seperti etnografi dan fenomenologi. Pengabungan rancangan studi kasus dengan rancangan fenomenologi dikarenakan penelitian ini memiliki hubungan dengan esensi pengalaman seseorang terkait suatu fenomena.

Penelitian ini dilakukan di beberapa daerah di Propinsi Jawa Timur. Adapun alasan dari pengambilan lokasi penelitian yang berlokasi di Jawa Timur adalah karena masih terdapat akses peneliti untuk dapat berhubungan dan mendapatkan data dari para subjek yang diteliti. Penelitian ini mengambil data dari 3 orang partisipan. Secara umum partisipan tersebut adalah orang - orang yang terlibat dan menjadi pelaku pembunuhan anggota PKI. Metode pengumpulan data yang digunakan dalam penelitian ini adalah wawancara, observasi, dan studi dokumen. teknik wawancara yang dipakai adalah wawancara tak terstruktur secara mendalam (in depth). Hanurawan (2016) menjelaskan jenis wawancara tak terstruktur secara mendalam atau informal konvensional adalah wawancara yang bersifat spontan dan sangat tidak terstruktur. Dalam pelaksanaan proses wawancara ini, pewawancara dan subjek melakukan diskusi tentang sebuah topik yang kemudian diikuti oleh pendalaman terhadap isu - isu yang muncul disekitar topik tersebut.

Teknik analisis data yang digunakan adalah teknik analisis tematik. Teknik analisis ini adalah analisis makna berdasar tema-tema yang menonjol yang berhubungan dengan kategori-kategori yang ada dalam tujuan penelitian (Hanurawan, 2016). Tahap - tahap analisis data terbagi menjadi tiga tahapan, peneliti merujuk kepada tahapan analisis data yang dikemukakan oleh Miles dan Huberman (2014), yakni: (1) Reduksi Data, (2) Penyajian Data, dan (3) Penarikan Kesimpulan. Sedangkan keabsahan data dalam penelitian ini mengunakan validitas interpretif. Hanurawan (2016) menjelaskan jenis validitas ini 
merupakan keabsahan deskripsi secara akurat makna subjektif terdalam (inner subjective meaning) yang dikemukakan oleh subjek tentang objek fenomena penelitian. Pengecekan keabsahan data dilakukan dengan membandingkan data penelitian yang diperoleh dengan beberapa sumber data yang lain.

\section{HASIL}

Berdasarkan hasil penelitian diketahui bahwa ketiga partisipan penelitian mengungkapkan keadilan merupakan sebuah keseimbangan dalam berbagai hal, utamanya dalam keamanan dan kedamaian, serta segala upaya untuk mencapainya merupakan bagian yang tak bisa dipisahkan dari keadilan itu sendiri. Seluruh partisipan telah mengalami berbagai hal yang bersinggungan langsung maupun tidak langsung dengan PKI jauh sebelum melakukan pembunuhan anggota PKI. Mereka mengaku bahwa PKI telah banyak membuat kekacauan dan membahayakan hidup mereka.

Kondisi tempat tinggal partisipan memliki andil dalam pembentukan persepsi keadilan partisipan. Berdasarkan hasil catatan lapangan yang telah dikumpulkan, ditemukan bahwa tempat tinggal partisipan dulunya merupakan daerah yang dijadikan basis kekuatan oleh PKI serta merupakan daerah yang mengalami konflik langsung antara PKI dan partisipan secara individu maupun secara kelompok. Beragam konflik yang melibatkan partisipan dan PKI tersebut telah berandil besar dalam membentuk persepsi keadilan yang dimiliki oleh partisipan.

Partisipan memiliki keyakinan bahwa pembunuhan anggota PKI yang dilakukan pada tahun 1965 merupakan perbuatan yang adil. Persepsi keadilan yang dimiliki partisipan menyangkal bahwa PKI adalah korban dalam konteks tahun 1965. Partisipan mempersepsikan PKI sebagai ancaman yang apabila tidak dilakukan tindakan maka mereka yang akan menjadi korban. Hal itu dapat terlihat pada saat partisipan menceritakan bahwa PKI tidak selalu ada pada posisi yang lemah pada waktu sebelum 1965. Demikian halnya dengan deskripsi yang dikemukakan oleh partisipan bahwa PKI yang telah banyak menebar ancaman baik kepada partisipan secara pribadi maupun secara luas. Oleh karena hal tersebut mendasari persepsi partisipan bahwa pembunuhan adalah hal yang memang harus dilakukan. Selain itu, hasil penelitian juga mendapatkan tiga konsep persepsi keadilan yang dikemukakan oleh partisipan sebagai berikut.

\section{Persepsi Keadilan Protektif}

Kesemua partisipan penelitian memiliki persepsi keadilan yang telah memenuhi persepsi keadilan dalam bentuk persepsi keadilan protektif. Partisipan penelitian secara umum merasa terancam dengan gerakan PKI yang pada tahun 1965 berkembang dengan sangat pesat. Mereka menilai pembunuhan anggota PKI yang telah dilakukan tidak ada salahnya dan merupakan hal yang adil untuk dilakukan. Mereka lebih memilih untuk bertindak, yakni membunuh anggota PKI terlebih dahulu ketimbang mereka yang akan menjadi korban seperti kejadian yang telah terjadi di tahun 1948.

\section{Persepsi Keadilan Prosedural}

Berdasarkan uraian dan data yang telah dikumpulkan, dapat dideskripsikan bahwa partisipan memiliki persepsi keadilan yang telah dapat memenuhi bentuk persepsi keadilan prosedural utamanya terhadap aturan pemerintah yakni Ketetapan MPRS No. 25 tahun 1966 tentang pembubaran PKI dan pelarangan paham komunisme yang masih berlaku sampai saat ini. Namun tidak semua partisipan mengutarakan secara jelas dan lengkap terkait keadilan prosedural dalam persepsi keadilan mereka. Secara umum partisipan penelitian kesemuannya mengakui bahwa pembunuhan anggota PKI tahun 1965 dilakukan setelah adanya arahan dari pemerintah Indonesia. Arahan yang menyebutkan bahwa PKI dan ideologi komunisme pada saat itu merupakan organisasi terlarang serta ideologi yang dilarang di Indonesia.

\section{Persepsi Keadilan Retributif}

Kesemua partisipan penelitian memiliki persepsi keadilan yang telah memenuhi bentuk persepsi keadilan retributif. Partisipan 
mempersepsikan bahwa pembunuhan yang dilakukan merupakan retribusi atau bentuk hukuman atas kejahatan yang dilakukan oleh PKI. Kekejaman PKI dan kerugian yang ditimbulkan pada saat PKI masih memiliki kekuatan dan pengaruh yang luar biasa, merupakan salah satu penyebab utama pembunuhan yang dilakukan oleh partisipan. PKI telah banyak membuat kekacauan dan kerugian dimana - mana, secara umum kesemua partisipan menyetujui hal tersebut. Semenjak tahun 1948, pada saat terjadi pemberontakan di Madiun, partisipan telah bertemu dan merasakan sendiri yang dilakukan PKI di daerahnya. Pembunuhan, perampasan, dan banyak hal yang keji dilakukan. Belum lagi permasalahan penistaan agama yang juga banyak terjadi pada saat PKI memiliki pengaruh yang kuat di tahun 1960 an.

\section{Persepsi Keadilan Restoratif}

Persepsi keadilan restoratif secara umum terpenuhi pada semua partisipan penelitian yang menganggap bahwa pembunuhan adalah upaya mengembalikan kondisi yang kacau pada saat PKI memiliki kekuatan dan pengaruh. Pada saat munculnya Gerakan 30 September 1965, terjadi kondisi yang sangat genting dirasakan oleh semua partisipan. Kondisi yang genting tersebut juga sebenarnya telah dirasakan sebelum terjadinya G30S. Telah banyak diceritakan di awal, bahwa terjadi banyak aksi - aksi provokatif yang dilakukan oleh PKI yang membuat kondisi semakin tak terkendali. Kondisi tersebut membuat partisipan merasa perlu dilakukan suatu upaya pengendalian demi menyelamatkan kondisi yang amat kacau.

\section{PEMBaHASAN}

Berdasarkan hasil penelitian ditemukan bahwa partisipan memiliki sebuah pemahaman yakni pembunuhan yang dilakukan merupakan hal yang adil merujuk pada beberapa bentukbentuk keadilan yang ada. Keadilan sendiri secara umum dipahami oleh partisipan sebagai keseimbangan dalam berbagai hal, utamanya dalam keamanan dan kedamaian, serta segala upaya untuk mencapainya merupakan bagian yang tak bisa dipisahkan dari keadilan itu sendiri. Pembunuhan anggota PKI sebagai suatu keadilan dibentuk dari rentetan peristiwa, pengalaman, dan kesan yang telah membekas dalam benak partisipan selama bersinggungan dengan PKI lalu akhirnya melakukan pembunuhan pada anggota PKI.

Secara protektif, persepsi keadilan partisipan terbentuk dari penilaian partisipan tentang PKI yang banyak memberikan ancaman pada partisipan. Ancaman tersebut membuat partisipan melakukan pembunuhan sebagai proteksi diri dari gangguan PKI secara individual maupun secara organisasi. Selain itu, partisipan memiliki persepsi bahwa secara prosedur pembunuhan anggota PKI telah sesuai dengan aturan yang ditetapkan pemerintah. Peraturan yang dimaksud partisipan adalah ketetapan bahwa PKI merupakan organisasi terlarang akibat dari pemberontakan yang dilakukan PKI pada tahun 1965.

Persepsi keadilan partisipan dalam bentuk retributif juga menunjukkan bahwa pembunuhan adalah bentuk retributif atau hukuman dari partisipan kepada anggota PKI berdasarkan kejahatan yang telah dilakukan oleh PKI sebelumnya. Kejahatan - kejahatan yang dilakukan oleh PKI sampai saat ini masih terangkum jelas dibenak partisipan. Persepsi keadilan partisipan dalam bentuk restoratif juga tidak jauh berbeda dengan menjelaskan bahwa partisipan menganggap pembunuhan juga sebagai upaya untuk memperbaiki kondisi masyarakat yang kacau menjadi lebih baik. Sehingga dapat disimpulkan bahwa partisipan memiliki persepsi bahwa pembunuhan anggota PKI yang telah dilakukan adalah sesuatu yang dibutuhkan dan dapat dibenarkan oleh dirinya dan lingkungannya pada masa tersebut.

\section{KESIMPULAN}

Berdasarkan penelitian yang telah dilakukan, dapat disimpulkan bahwa: (1) Keadilan dipahami oleh partisipan sebagai keseimbangan dalam berbagai hal, utamanya dalam keamanan dan kedamaian, serta segala upaya untuk mencapainya merupakan bagian yang tak bisa dipisahkan dari keadilan itu sendiri. (2) Partisipan memiliki persepsi bahwa pembunuhan anggota PKI yang dilakukan pada tahun 1965 merupakan perbuatan yang adil. Persepsi keadilan yang dimiliki partisipan menyangkal bahwa PKI adalah korban dalam 
konteks tahun 1965. Partisipan mempersepsikan PKI sebagai ancaman yang apabila tidak dilakukan tindakan maka mereka yang akan menjadi korban. (3) Semua partisipan memiliki persepsi keadilan yang telah memenuhi persesi keadilan protektif. Partisipan memiliki pemahaman bahwa pembunuhan anggota PKI adalah upaya perlindungan diri dari ancaman. (4) Pada persepsi keadilan prosedural partisipan memiliki pemahaman bahwa pembunuhan anggota PKI sebagai bentuk keadilan dengan ketaatan terhadap aturan negara. Ketetapan yang dimaksud adalah ketetapan MPRS No. 25 tahun 1966 tentang pembubaran PKI dan pelarangan komunisme. (5) Persepsi keadilan retributif dimiliki oleh semua partisipan dimana mereka menilai kejahatan yang PKI lakukan pantas untuk mendapatkan hukuman yang setimpal. (6) Persepsi keadilan restoratif juga dimiliki semua partisipan yang mempersepsikan bahwa pembunuhan anggota PKI merupakan tindakan yang adil untuk dilakukan karena bertujuan untuk memulihkan kondisi yang sangat kacau akibat aksi PKI.

\section{SARAN}

Berdasarkan hasil penelitian, kepada pelaku pembunuhan anggota PKI disarankan untuk memberikan pemahaman lebih kepada generasi muda serta tidak membatasi pengetahuan dan pengalaman, sehingga informasi dan pengetahuan yang berkembang lebih berimbang. Dalam proses rekonsiliasi yang tengah digalakkan, partisipan juga diharapkan agar lebih banyak menceritakan pandangan dan pengalaman yang dialami, sehingga rekonsiliasi dapat berhasil dengan lebih terbuka dan berimbang. Kepada masyarakat hendaknya dapat menilai secara utuh peristiwa tahun 1965 sebagai suatu proses bernegara. Penilaian satu sisi hanya menimbulkan permasalahan yang tidak terdapat jalan penyelesaian. Pemerintah juga dapat mengunakan penelitian ini sebagai salah satu bahan masukan dalam rangka permasalahan tahun 1965. Pemerintah hendaknya membuka diri seluas - luasnya terhadap setiap informasi dan masukan, agar dapat tercapai rekonsiliasi yang tengah dicita-citakan. Peneliti selanjutnya yang akan membahas persepsi keadilan atau peristiwa tahun 1965 disarankan untuk lebih memperhatikan rapport pada saat pengambilan data. Hal ini dikarenakan topik yang dipilih merupakan topik yang masih sensitif dan banyak orang masih takut serta trauma dengan topik yang dibahas. Oleh karena itu dengan raport yang lebih baik maka data yang akan diperoleh akan lebih baik dan penelitian menghasilkan temuan yang lebih baik dan bermanfaat pula.

\section{DAFTAR RUJUKAN}

Amalia, Rizqy. 2012. Analisis Pengaruh Peranan Persepsi Keadilan Terhadap Komitmen Afektif dan Kepuasan Kerja di Antara Karyawan Non-Keluarga. Skripsi. Universitas Indonesia.

Anam, Choirul. 1990. Gerak Langkah Pemuda Ansor Sebuah percikan. Sejarah Kelahiran. Surabaya: Majalah Nahdlatul Ulama AULA.

Antaranews,com. 27 Mei 2016. Taufiq Ismail: Komunis Bantai 120 Juta Orang Di 75 Negara. (online). http://www.antaranews.com/berita/563610/taufi q-ismail-komunis-bantai-120-juta-orang-di-75negara. Diakses pada 30 Mei 2016.

Atkinson, R. L. 1991. Pengantar Psikologi. Jakarta: Erlangga.

Bachri, Rifkiyati. 2010. Pembunuhan Berencana Dan Mutilasi. Jurnal Yudisial Vol. III No. 02.

bbc.com. 1 Oktober 2015. Jumat Pagi Bersama 'Algojo Pemburu' PKI. (online). http://www.bbc.com/indonesia/berita_indonesia /2015/10/150922_indonesia_lapsus_penolakan masyarakat. Diakses pada 30 Mei 2016.

Chan, David. 2011. The Perceived Fairness Of Process And Treatment Is As Significant As Outcomes When Engaging Employees, Stakeholders Or The Public. (online).

https://www.cscollege.gov.sg/knowledge/ethos/i ssue $\% 2010 \% 20$ oct $\% 202011 /$ pages/Perceptions \%20of\%20Fairness.aspx. Diakses pada 8 Agustus 2016.

Chaplin, J. P. 2011. Kamur Lengkap Psikologi. Jakarta: PT Raja Grafindo.

Cohn, Ellen S. White, Susan O. Sanders Joseph. 2000. Distributive and Prosedural Justice in Seven Nations. Journal of Law and Human Behavior American Psychology-Law 
Society/Division 41 of American Psychology Association Vol. 24 No. 5, (online), (www.proquest.com). Diakses pada 15 Oktober 2015.

Cribb, Robert. Coppel, Charles A. 2009. A Genocide That Never Was: Explaining The Myth of Anti-Chinese Massacres in Indonesia, 1965-66. Journal of Genocide Research vol. 11 no. 4.

Darmodiharjo dan Shidarta, 1995. Pokok - Pokok Filsafat Hukum. Jakarta: Gramedia Pustaka Utama.

Faturochman. 1999. Keadilan Sosial: Suatu Tinjauan Psikologi. Buletin Psikologi, Tahun VII, No.1, Juni 1999, (online). (www.portalgaruda.com). Diakses pada 15 Oktober 2015.

Fic, Victor M. 2005. Kudeta 1 Oktober 1965: Sebuah Studi Tentang Konspirasi. Jakarta: Yayasan Obor.

Gerungan. 2010. Psikologi Sosial. Bandung: PT. Refika Aditama.

Hanurawan, Fattah. 2012. Metode Penelitian Kualitatif Dalam Ilmu Psikologi. Surabaya: KPKM Universitas Airlangga.

Hanurawan, Fattah. 2010. Pengantar Psikologi Sosial. Bandung: Rosdakarya.

Hanurawan, F. dan Partino. 2001. Kontroversi pendekatan kuantitatif dan pendekatan kualitatif dalam penelitian psikologi. Malang : Universitas Negeri Malang.

Herdiansyah, Haris. 2015. Metodologi Penelitian Kualitatif Untuk Ilmu Psikologi. Jakarta: Salemba Humanika.

Hermoyo, B. 2012. Peranan Filsafat Hukum Dalam Mewujudkan Keadilan. Jurnal Wacana Hukum. Vol 9, No 2.

Komnas Ham. (2012). Ringkasan Eksekutif Laporan Penyelidikan Pelanggaran Ham Berat. Jakarta: KOMNASHAM RI.

Levin, Mark Sh. 2006. Composite Systems Decisions. Springer (Online) http://www.springer.com/us/book/97818462800 16 diakses pada 25 November 2015.

Kompas.com. 23 September 2015. Inilah Memo CIA Soal PKI dan Gerakan 30 September $1965 . \quad$ (Online). http://dunia.tempo.co/read/news/2015/09/18/11 6701837/inilah-memo-cia-soal-pki-dangerakan-30-september-1965. Diakses pada 13 November 2015.
Kompas.com. 29 September 2015. Membersihkan Dosa Kolektif G30S. (Online). http://nasional.kompas.com/read/2015/09/29/16 000001/Membersihkan.Dosa.Kolektif.G30S?pa ge=all. Diakses pada 15 Mei 2016.

Maksum, Ali. Bustami, Reevany. 2013. The 1965 Coup and Reformasi 1998: Two Critical Moments in Indonesia - Malaysia Relationship During and After Cold War. SpringerPlus $2013 \quad 3: 45 . \quad$ (online). (http://www.springerplus.com/content/3/1/45) Diakses pada 15 Oktober 2015.

Miles, Matthew \& Hubermman, Michael. 2014. Analisis Data Kualitatif : Buku Sumber Tentang Metode - Metode Baru. Jakarta : UI Press.

Moleong, Lexy J. 2013. Metodologi Penelitian Kualitatif Edisi Revisi. Bandung. Remaja Rosdakarya.

Pengadilan Rakyat Tragedi 1965 Akan Diadakan di Den Haag. 2015, Agustus. (online).http://nasional.tempo.co/read/news/201 5/08/13/078691518/pengadilan-rakyat-tragedi1965-akan-diadakan-di-den-haag diakses pada 10 November 2015

Poerwandari, Kristi. 2013. Pendekatan Kulitatif untuk Penelitian Perilaku Manusia. Depok: LPSP3.

Poesponegoro, Marwati Djoened., Notosusanto, Nugroho. (1984). Sejarah Nasional Indonesia VI. Jakarta: Balai Pustaka Departemen Pendidikan dan Kebudayaan.

Rahim, M. Afzalur. Magner, Nace. Shapiro, Debra L. 2000. Do Justice Perception Influence Styles Of Handling Conflict With Supervisors? : What Justice Perceptions, Precisely?. The International Journal of Conflict Management (2000) Vol. 11 No. 1. (www.Proquest.com). Diakses pada 25 Oktober 2015 .

Rawls, John. 1999. A Theory of Justice. Massachusetts: Harvard University Press.

Roeckelein, John E. 2013. Kamus Psikologi: Teori, Hukum, dan Konsep. Jakarta: Kencana.

Rofiah, Nur. Hafidz, Masykurudin. 2010. Memecah Kebisuan - Respon NU: Agama Mendengar Suara Perempuan Korban Kekerasan Demi Keadilan. Jakarta: Komnas Perempuan. 
Roosa, John. 2008. Dalih Pembunuhan Massal: Gerakan 30 September dan Kudeta Suharto. Jakarta: Hasta Mitra.

Pusat Bahasa Departemen Pendidikan Nasional (Eds.). 2008. Kamus Bahasa Indonesia. Jakarta: Pusat Bahasa.

Sagala, Ediman. 2014. Persepsi Keadilan Atas Kompensasi Langsung Beserta Dampaknya Terhadap Kinerja Pegawai Non Akademik (Kepala Bagian). Skripsi. Universitas Kristen Satya Wacana.

Salam, Syukron. Adhivira, Rian. 2015. On Legal Authority and Justice: Law and Authority During State-Of-Exception, Study on Indonesia 1965-66 Gross Violations of Human's Right. Makalah Disajikan dalam the Paul Scholten Workshop: New Perspective on Law and Reality. DPSP Project, University of Amsterdam. November 2015.

Salim, Hairus. 2004. Kelompok Paramiliter NU. Jogjakarta: PT LKIS Pelangi Aksara.

Saputro, Legowo. 2015. Keadilan restoratif dan Sistem Peradilan Pidana di Indonesia. (online) https://www.academia.edu/attachments/427196 21/download_file?st=MTQ2MzkwMTkxMCwx MTIuMjE1LjQ0LjExMSwyMTgwNjk2Nw\%3 $\mathrm{D} \% 3 \mathrm{D} \& \mathrm{~s}=\mathrm{swp}-$ toolbar\&ct=MTQ2MzkwNTE1NiwxNDYzOT A1MTU3LDIxODA2OTY3. Diakses pada 20 April 2016.

Sobur, Alex. 2009. Psikologi Umum Dalam Lintasan Sejarah. Bandung: Pustaka Setia

Sobur, Alex. 2003. Psikologi Umum Dalam Lintasan Sejarah. Bandung: Pustaka Setia.

Supriyono. 2014. Keadilan Restributif dan Restoratif. (online). http://mediasikonflik.com/keadilan-retributifdan-restoratif/. Diakses pada 30 Mei 2016.

Susanto, Nur Agus. 2014. The Axiological Dimension from the Case Decision Of "ST". Jurnal Yudisial. Vol. 7, No. 3 (2014): $213-235$

Suteki. Adhivira, Rian. 2015. 1965 dan Masa Depan Hukum di Indonesia. Makalah disajikan dalam Konferensi Asosiasi Filsafat Hukum Indonesia, Universitas Muhammadiyah Surakarta, Solo, 17-18 November 2015.
Sunyoto, Agus. 1996. Banser Berjihad Menumpas PKI. Tulungagung: Lembaga Kajian dan Pengembangan Pesulukan Thoriqoh Agung (PETA).

Siswosoebroto, Koesriani. 2009. Pendekatan Baru dalam Kriminologi. Jakarta: Penerbit Universitas Trisakti.

Tempo. 7 Oktober 2012. Pengakuan Algojo 1965, hlm. 56 - 59.

Tempo.co. 1 Oktober 2012. Untuk Tabok PKI, Tentara Pinjam Tangan Rakyat. 2012, Oktober. (Online). http://nasional.tempo.co/read/news/2012/10/01/ 078432910/untuk-tabok-pki-tentara-pinjamtangan-rakyat. Diakses pada 15 November 2015.

Universitas Negeri Malang. 2010. Pedoman Penulisan Karya Ilmiah: Skripsi, Tesis,Disertasi, Artikel, Makalah, Laporan Penelitian. Edisi Kelima. Malang: Biro Administrasi Akademik, Kemahasiswaan, Perencanaan, dan Sistem Informasi bekerja sama dengan Penerbit Universitas Negeri Malang

Walgito, Bimo. 2004. Pengantar Psikologi Umum. Yogyakarta: Andi.

Willig, Carla. 2013. Introducing Qualitative Research In Psychology Third Edition. New York: Open University Press.

Witvliet, C.V.O., Worthington, E.L., Jr., Root, L.M., Sato, A.F., Ludwig, T.E., \& Exline, J.J. 2008. Retributive Justice, Restorative Justice, And Forgiveness: An Experimental Psychophysiology Analysis. Journal of Experimental Social Psychology, 44, 10-25.

Weiss, Stanley. 2003. Perception Is Everything!. Dental Economics (2003). (online) www.ProQuest.com. Diakses pada 25 Oktober 2015.

Wertheim. 1970. Suharto and the Untung Coup - Th e Missing Link. Journal of Contemporary Asia 1, No. 2 (1970): 50-57.

Wuryanto, Danu Adi, Suharmono. 2012. Analisis Pengaruh Promosi Jabatan, Persepsi Keadilan Kompensasi dan Lingkungan Kerja Fisik Terhadap Kepuasan Kerja Karyawan (Studi Pada Karyawan PT. Suara Merdeka Press). Ejournal S1Universitas Diponegoro. Volume 1, Nomor 1, Tahun 2012, Halaman 112.

Yunitasari, Herma. Yuniawan, Ahyar. 2006. Analisis Pengaruh Kesadaran Merek, 
30| Jurnal Sains Psikologi, Jilid 6, Nomor 1, Maret 2017, hlm 22-30

Persepsi Kualitas Dan Loyalitas Merek Terhadap Nilai Pelanggan Mobil Merek Toyota. Jurnal Studi Manajemen \& Organisasi Volume 3, Nomor 2.
Zulfa, Eva. 2010. Keadilan Restoratif Dan Revitalisasi Lembaga Adat Di Indonesia. Jurnal Kriminologi Indonesia Vol. 6 No.II 182 Agustus 2010: 182 - 203. 